\title{
Oestrogen does not affect the restoration of spermatogenesis in the gonadotrophin-releasing hormone-immunised adult rat
}

\author{
Sarah J Meachem, David M Robertson, Nigel G Wreford', \\ Robert I McLachlan and Peter G Stanton \\ Prince Henry's Institute of Medical Research Block E, Level 4, Monash Medical Centre, 246 Clayton Road, Clayton, Victoria 3168, Australia \\ ${ }^{1}$ Department of Anatomy and Cell Biology, Monash University, Clayton, Victoria 3168, Australia \\ (Requests for offprints should be addressed to Sarah Meachem; Email: sarah.meachem@phimr.monash.edu.au)
}

\begin{abstract}
Oestrogen is a metabolite of testosterone, but its role in spermatogenesis is ill-defined. Oestrogen may exert its effects on spermatogenesis, as oestrogen receptor (ER)- $\beta$ has been localised to both germ and somatic cells. This study sought to establish whether the restoration of early germ cell numbers in spermatogenesis by high-dose exogenous testosterone was influenced by its metabolite, oestrogen. The ER antagonist (ICI 182780) was administered, at a dose known to impair oestrogen action in the male reproductive tract, during testosterone treatment of gonadotrophin-releasing hormone $(\mathrm{GnRH})$-immunised rats, and germ cell numbers were determined. GnRHimmunised adult Sprague-Dawley rats $(n=7-8$ per group) received two doses of testosterone, either as a Silastic implant $(24 \mathrm{~cm}(\mathrm{~T} 24 \mathrm{~cm}))$ or an injectable ester for 10 days alone or in combination with ICI $182780(2 \mathrm{mg} / \mathrm{kg}$, s.c. injection daily). Control rats received vehicle alone. Testes were perfusion-fixed and germ cells were quantified by the optical disector technique.

GnRH-immunisation reduced $(P<0 \cdot 001)$ both type A/ intermediate spermatogonial and type B spermatogonial/
\end{abstract}

preleptotene spermatocyte number (56\% of control) and leptotene/zygotene spermatocyte number (63\% of control). Pachytene spermatocyte and round spermatids were reduced to $12 \%$ and $1 \%(P<0 \cdot 01)$ of control respectively. Testosterone treatment did not increase type $\mathrm{A} /$ intermediate spermatogonial number compared with GnRH-immunised controls over the 10-day study period. Treatment with testosterone-esters increased type B spermatogonial/preleptotene spermatocytes and leptotene/zygotene spermatocyte numbers (both being $\sim 83 \%$ of control, $P<0 \cdot 05)$, while T24 cm treatment did not significantly increase their numbers ( $\sim 73 \%$ of control) compared with GnRH-immunised controls. Both treatments increased pachytene spermatocyte and round spermatid numbers to $55 \%$ and $8 \%$ of control respectively. Co-administration of ICI 182780 had no effect on any of these germ cell numbers. We conclude that oestrogen action plays no role in the short-term restoration of spermatogenesis by testosterone in the GnRH-immunised rat.

Journal of Endocrinology (2005) 185, 529-538

\section{Introduction}

A direct role for oestrogens in the regulation of spermatogenesis is difficult to establish in vivo as the administration of oestrogens to adult rats reduces both luteinising hormone (LH)/testosterone and follicle-stimulating hormone (FSH) secretion thereby producing a similar histological appearance to that of hypophysectomy (reviewed in O'Donnell et al. 2001). Oestradiol has been reported to induce spermatogenesis in the $h p g$ mouse model, although this may be via stimulatory effects on FSH secretion (Ebling et al. 2000). Mice lacking the functional oestrogen receptor- $\alpha(\mathrm{ER} \alpha)$ (Eddy et al. 1996) and aromatase gene (ArKO) have impaired spermatogenesis (Robertson et al. 1999). The adult ER $\alpha$ knock-out testis is grossly dismorphic, probably due to back pressure of luminal fluids as oestrogen regulates fluid reabsorption in the head of the epididymis (Hess et al. 1997). Normal rats (Oliveira et al. 2001, 2002) and mice (Cho et al. 2003) treated with an ER antagonist (ICI 182780) also provide compelling evidence that testicular disruption is secondary to dilation of the rete testis and efferent ductule lumens due to lack of action by an oestrogen-dependent $\mathrm{Na}^{+} / \mathrm{H}^{+}$exchanger necessary for fluid and electrolyte reabsorption (Zhou et al. 2001). On the other hand, a lack of a direct oestrogenic effect on the seminiferous epithelium is thought to account for the phenotype seen in the ArKO mouse wherein germ cells early in spermiogenesis are the primary site of impairment with no changes being reported in spermatogonial number (Robertson et al. 1999). Spermatogenesis in the $\operatorname{ER} \beta$ knock-out animal is presumed normal as mice are fertile (Krege et al. 1998), which is surprising given that 
ER $\beta$ is present on Sertoli and germ cells, while the combined ER $\alpha \beta$ knock-out animal exhibits a similar phenotype to the ER $\alpha$ knock-out mouse (Couse et al. 1999, Dupont et al. 2000).

Spermatogenesis is regulated by FSH and testosterone independently and synergistically (McLachlan et al. 2002). In brief, FSH plays a major role in regulating spermatogonial development in the adult rat (Meachem et al. 1998, 1999). Both FSH and testosterone support spermatocyte maturation, while testosterone is considered essential for spermatid development. In rodent and human models of combined FSH and testosterone deficiency, severe spermatogenic disruption is observed (McLachlan et al. 2002). For example in the gonadotrophin-releasing hormone (GnRH)-immunised rat, a model that lacks both FSH and $\mathrm{LH} /$ testosterone, reductions in spermatogonial and spermatocyte populations to $50 \%$ and $10 \%$ of control, respectively, are observed while mature spermatids disappear. Exogenous testosterone (e.g. $24 \mathrm{~cm}$ Silastic s.c. implant) restores spermatogenesis to near normal by partially restoring testicular testosterone levels (to 10-20\% of control) and by the restoration of pituitary FSH by GnRH-independent mechanisms (Meachem et al. 1998, Pratis et al. 2003). This restoration of serum FSH is not always observed (Awoniyi et al. 1989). Whether testosterone-induced spermatogenesis is influenced by a metabolite of testosterone (e.g. oestrogen) is not known. Other data have reported that spermatogenesis is supported by the non-aromatisable androgen dihydrotestosterone (DHT), suggesting that aromatisation is not an absolute requirement in gonadotrophin-deficient mice (Singh et al. 1995) and rats (Huang et al. 1987).

In regard to the restoration of spermatogonial development by exogenous testosterone, the data are conflicting. Low-dose testosterone (6 cm Silastic implants) was ineffective in restoring spermatogonial development in GnRH-immunised rats (Meachem et al. 1998), but other studies have shown that low doses of testosterone stimulates spermatogonial number in the hypophysectomised rat (Huang et al. 1987, Sun et al. 1989). On the other hand, an inhibition of spermatogonial development has been suggested in studies using high doses of exogenous testosterone (24 cm Silastic implants) in the GnRH-immunised rat model which may be the reason that spermatogenesis is not quantitatively normal (McLachlan et al. 1994a). Meistrich and colleagues have provided compelling evidence that high testicular testosterone levels inhibited spermatogonial development following exposure to radiation (Meistrich \& Kangasniemi 1997, Shuttlesworth et al. 2000) or chemotherapeutic procarbazine in rats (Meistrich et al. 1999), and in the juvenile spermatogonial depletion mutant mouse model (Matsumiya et al. 1999, Shetty \& Weng 2004). The mechanism by which testosterone might regulate spermatogonial development in these paradigms is unclear, however it is postulated that a metabolite of testosterone, such as oestrogen, may be involved and this concept is plausible since ER $\beta$ has been immunolocalised to the rat Sertoli cell and spermatogonia (Saunders et al. 1998).

In order to explore the role of oestrogen in the regulation of spermatogenesis, we examined the restoration of rat germ cell number following a period of regression induced by $\mathrm{GnRH}$-immunisation. In this model, exogenous testosterone treatment partially restores sperm production by both stimulating pituitary FSH secretion and by partially restoring testicular testosterone levels, with the latter also providing substrate for aromatisation to oestrogen. The aim of this study was to determine whether the restoration of spermatogenesis by exogenous testosterone was affected by the inhibition of oestrogen action that was achieved by the coadministration of the potent ER antagonist ICI 182780, which targets both ER $\alpha$ and ER $\beta$ (Kuiper et al. 1997, Tremblay et al. 1998, Wakeling 2000). The germ cell response was quantified using the optical disector (sic) stereological technique.

\section{Materials and Methods}

\section{Animals}

Adult Sprague-Dawley rats (75-90 days of age, 350$450 \mathrm{~g})$ were obtained from the Monash Animal House (Clayton, Australia) and maintained at $20^{\circ} \mathrm{C}$ in a fixed $12 \mathrm{~h}$ light: $12 \mathrm{~h}$ darkness cycle with free access to food and water. This study was approved by the Monash University Animal Ethics Committee.

\section{Steroid implants}

Testosterone (Sigma) Silastic implants (Dow Corning, Corp., Midland, MO, USA) were prepared using medical-grade polydimethylsiloxane tubing (Dow Corning; inner diameter, $1.98 \mathrm{~mm}$; outer diameter, $3.18 \mathrm{~mm}$ ), and medical adhesive silicone type A as previously described (Robaire et al. 1979). Testosterone implants were $8 \mathrm{~cm}(3 \times 8 \mathrm{~cm}=24 \mathrm{~cm})$ in length.

\section{Experimental design: spermatogenic suppression}

Adult rats were actively immunised with a proprietary GnRH immunogen preparation (BA-1666-4, Biotech, Sydney, Australia) incorporating an adjuvant free of mycobacterial components (Stewart et al. 1992). The immunisation protocol and its effects have been described previously (McLachlan et al. 1994a). Briefly, the GnRH immunogen was administered at a dose of $100 \mu \mathrm{g}$ protein at a single site every 4 weeks until completion of the study. The control rats received adjuvant only. The response to immunisation was assessed after 12 weeks by measuring testicular volumes by palpation under anaesthesia. 
A testicular regression to less than $0.55 \mathrm{ml}$ was considered to be an indication of successful immunisation (McLachlan et al. 1994b). All rats showed testicular regression and received a final booster at week 12 .

\section{Experimental design: spermatogenic restoration}

In order to study the effects of testosterone on the restoration of spermatogenesis in the absence and presence of oestrogen, GnRH-immunised rats $(n=7-8$ per group) received testosterone Silastic implants $(\mathrm{T} 24 \mathrm{~cm})$ or subcutaneous testosterone esters (25 mg per rat (T25 mg) Sustanon 100 (20\% testosterone propionate $+40 \%$ testosterone phenylpropionate $+40 \%$ testosterone isocaproate); Organon Australia, Sydney) every third day) for 10 days in combination with either the ER antagonist ICI 182780 ( $2 \mathrm{mg} / \mathrm{ml}$ ICI 182780 in oil per kg body weight, s.c. daily injection (Faslodex-Astra-Zeneca, Macclesfield, UK)) or vehicle. ICI 182780 was dissolved in absolute ethanol, and then peanut oil $(1: 9, \mathrm{v}: \mathrm{v})$ was added prior to evaporation of the solvent under a $\mathrm{N}_{2}$ gas stream. The vehicle was prepared in the same way but the drug was omitted.

This dose of ICI 182780 was chosen based on the following criteria: (i) a 10-fold lower dose compared with that used in this study blocked oestrogen action in human breast cancer patients (Howell et al. 2002) and prevented blastocyst implantation in rats (Dao et al. 1996); (ii) a similar dose to that used in this study disrupted the male reproductive tract of rodents, specifically by inducing dilation of the efferent ductules (Oliveira et al. 2001, 2002, Cho et al. 2003). Two doses of testosterone (T24 cm implant and T25 mg ester) were used to induce graded levels of serum testosterone to test whether higher levels of serum testosterone have detrimental effects on spermatogonial development.

Tissue collection The left testis was removed (prior to perfusion of the right testis) and frozen in liquid nitrogen and stored at $-80{ }^{\circ} \mathrm{C}$ prior to assessment of testicular oestrogen levels. As testicular oestrogen concentrations were a priority and tissue mass limited, testicular testosterone levels were not measured but have been previously well characterised in this model and reported elsewhere (McLachlan et al. 1995, Meachem et al. 1998, Pratis et al. 2003). Details of the testis perfusion procedure with Bouin's fixative, tissue collection, processing, methacrylate embedding, sectioning $(25 \mu \mathrm{m})$, periodic acid-Schiff's staining have been previously described (Meachem et al. 1997). Blood was collected by cardiac puncture prior to whole-body perfusion as previously described (Meachem et al. 1997).

Cell number estimates The optical disector method (reviewed in Wreford 1995) was used to determine the total number of cells per testis, as previously described (McLachlan et al. 1994b, Meachem et al. 1999). Germ cells were identified using morphological criteria of Russell and colleagues (Russell et al. 1990) as detailed elsewhere (McLachlan et al. 1994b). A total of between 80 and 160 nuclei of each cell type were counted per rat. A set of unbiased counting frames in each field (with the area of each frame being $1151 \mu^{2}$ ) was used to count spermatogonia and primary spermatocytes, whereas a set of 4 frames (with the area of each frame being $576 \mu \mathrm{m}^{2}$ ) was used to count round and elongated spermatids. Round spermatids were counted in 2 of the 4 counting frames depending on their frequency. As previously determined, no correction for shrinkage was necessary (McLachlan et al. 1995, Meachem et al. 1996). Germ cells were counted in the following categories: type A/intermediate spermatogonia; type B spermatogonia/preleptotene spermatocyte; leptotene/zygotene spermatocyte; pachytene spermatocyte associated with stages I to XIV; round (steps 1 to 8 ) and elongated spermatids (steps 9 to 19). Germ cells were initially categorised into smaller groupings, but given that no effects were found for testosterone alone or in combination with ICI 182780 , germ cells were grouped in broader categories.

\section{Hormone assays}

Serum LH was measured by an immunofluorometric assay as previously described (Haavisto et al. 1993). All samples were run in triplicate across one assay. The sensitivity of the assay was $7 \cdot 8 \mathrm{pg} / \mathrm{ml}$ with a within-assay coefficient of variation of $11 \cdot 0 \%$.

Serum testosterone levels were measured by RIA utilising iodinated histamine-testosterone in combination with an acidic buffer ( $\mathrm{pH} \mathrm{5.1)} \mathrm{to} \mathrm{disrupt} \mathrm{binding} \mathrm{between}$ testosterone and binding proteins in unextracted serum (O’Donnell et al. 1996a). Serum samples were assayed in triplicate across a single assay. Assay sensitivity was $0.6 \mathrm{ng} / \mathrm{ml}$ with a within-assay coefficient of variation of $6 \%$.

Serum FSH levels were measured using reagents from the NIDDK reagent program, including iodinated rat FSH (rFSH-8), rat FSH antiserum (rFSH-I7), normal rabbit serum, and rat FSH RP-2 as standard ranging from $0 \cdot 76-100 \mathrm{ng} / \mathrm{ml}$. Goat anti-rabbit immunoglobulin G $(\operatorname{IgG})$ was used as precipitating second antibody. All samples were assayed in triplicate within the one assay. The sensitivity of the assay was $1.56 \mathrm{ng} / \mathrm{ml}$, with a within-assay coefficient of variation of $14 \%$.

Serum and testicular oestrogen concentrations were determined following extraction on Sep-pak $\mathrm{C}_{18}$ cartridges (Waters, Bedford, MA, USA) in an identical manner as described elsewhere for testosterone extraction (O'Donnell 1996b). Steroid recoveries were monitored throughout by the parallel processing of a group $(n=7$ animals) of normal control rat sera and testes to which had been added $\sim 10000$ d.p.m. of radiolabelled $\left[{ }^{3} \mathrm{H}\right]$ oestradiol $\left(2,4,6,7,16,17-{ }^{3} \mathrm{H}(\mathrm{N})\right.$ oestradiol, $110-170 \mathrm{Ci} / \mathrm{mmol}$, 
Table 1 Testicular weight, serum testosterone, LH and FSH levels in normal adult rats that were GnRH-immunised for 12 weeks and then given testosterone ( $24 \mathrm{~cm}$ Silastic implant or $25 \mathrm{mg} / \mathrm{kg}$ injectable ester, every third day) alone or in combination with ICI 182780 (ER ant) for 10 days

\begin{tabular}{|c|c|c|c|c|c|c|}
\hline & $\begin{array}{l}\text { Testis } \\
\text { weight } \\
(\mathrm{g})\end{array}$ & $\begin{array}{l}\text { Serum } \\
\text { LH } \\
(\mathrm{pg} / \mathrm{ml})\end{array}$ & $\begin{array}{l}\text { Serum } \\
\text { testosterone } \\
(\mathrm{ng} / \mathrm{ml})\end{array}$ & $\begin{array}{l}\text { Serum } \\
\text { FSH } \\
(\mathrm{ng} / \mathrm{ml})\end{array}$ & $\begin{array}{l}\text { Serum } \\
\text { oestradiol } \\
(\mathrm{pg} / \mathrm{ml})\end{array}$ & $\begin{array}{l}\text { Testicular } \\
\text { oestradiol } \\
\text { (pg/g TW) }\end{array}$ \\
\hline \multicolumn{7}{|l|}{ Treatment } \\
\hline Control & $1 \cdot 88 \pm 0.07^{a}$ & $841 \pm 165$ & $2 \cdot 34 \pm 0 \cdot 26^{a}$ & $4 \cdot 01 \pm 0 \cdot 65^{a}$ & $1 \cdot 26 \pm 0 \cdot 25^{\mathrm{a}}$ & $17 \cdot 46 \pm 8 \cdot 50^{\mathrm{a}}$ \\
\hline GnRH-immunized & $0 \cdot 33 \pm 0.03^{b}$ & Undetect. & $0 \cdot 27 \pm 0.09^{b}$ & $1 \cdot 71 \pm 0 \cdot 14^{b}$ & $1 \cdot 64 \pm 0 \cdot 12^{\mathrm{ab}}$ & $61 \cdot 80 \pm 15 \cdot 17^{b}$ \\
\hline$+\mathrm{T} 24 \mathrm{~cm}$ & $0 \cdot 60 \pm 0.05^{c}$ & Undetect. & $25 \cdot 3 \pm 4 \cdot 31^{\mathrm{c}}$ & $2 \cdot 73 \pm 0.55^{\mathrm{c}}$ & $1 \cdot 65 \pm 0 \cdot 32^{\mathrm{ab}}$ & $40 \cdot 69 \pm 9 \cdot 91^{\mathrm{ab}}$ \\
\hline$+\mathrm{T} 24 \mathrm{~cm}+\mathrm{ER}$ ant & $0 \cdot 76 \pm 0 \cdot 13^{c}$ & Undetect. & $21 \cdot 3 \pm 4 \cdot 71^{\mathrm{c}}$ & Undetect. & NM & NM \\
\hline +T25 mg & $0 \cdot 60 \pm 0.03^{c}$ & Undetect. & $171 \cdot 7 \pm 10 \cdot 1^{d}$ & $4 \cdot 08 \pm 0 \cdot 29^{a c}$ & $2 \cdot 72 \pm 0 \cdot 44^{b}$ & $27 \cdot 44 \pm 5 \cdot 01^{\mathrm{ab}}$ \\
\hline$+\mathrm{T} 25 \mathrm{mg}+\mathrm{ER}$ ant & $0.65 \pm 0.02^{\mathrm{c}}$ & Undetect. & $131 \cdot 8 \pm 5 \cdot 89^{\mathrm{e}}$ & $2 \cdot 59 \pm 0 \cdot 20^{b c}$ & NM & NM \\
\hline
\end{tabular}

Data are means \pm S.E.M., $n=6-7$ rats per group, except for $n=4$ serum testosterone, GnRH-immunised group. Different letters denote significant differences between groups at or less than $P<0 \cdot 05$ (see text for specifics). NM, not measured; Undetect., values at or below sensitivity of assay (LH, $7 \cdot 8 \mathrm{pg} / \mathrm{ml}$; testosterone, $0.6 \mathrm{ng} / \mathrm{ml} ; \mathrm{FSH}, 1.56 \mathrm{ng} / \mathrm{ml}$; oestrogen, $0.8 \mathrm{pg} / \mathrm{ml}$ ); TW, testis weight.

NEN Life Science Products, Boston, MA, USA). These recoveries in the RIA tube were $91.9 \pm 6.0$ and $73 \cdot 2 \pm 7 \cdot 1 \%$ (mean \pm S.D.) for sera and testes respectively. Oestradiol concentrations were then determined by RIA using an in-house iodinated histamine-oestrogen tracer (10 000 c.p.m. per $100 \mu \mathrm{l}$ in assay buffer $(0 \cdot 1 \%(\mathrm{w} / \mathrm{v})$ gelatin in $0 \cdot 1 \mathrm{M}$ PBS $(0 \cdot 154 \mathrm{M} \mathrm{NaCl}), \mathrm{pH} 7 \cdot 4), 100 \mu \mathrm{l}$ primary antibody (rabbit anti-oestrogen 4410, Diagnostic Systems Laboratories, Webster, TX, USA) diluted 1:6 in assay buffer, and sample in a final volume of $400 \mu \mathrm{l}$. The assay was incubated for $1 \mathrm{~h}$ at ambient temperature and then overnight at $4{ }^{\circ} \mathrm{C}$, prior to the addition of second antibody $(100 \mu \mathrm{l}$ goat anti-rabbit IgG diluted 1:20 in assay buffer) for a further incubation at ambient temperature for $30 \mathrm{~min}$. Complexes were precipitated by the addition of $1 \mathrm{ml}$ of $6 \%$ polyethylene glycol 6000 for $30 \mathrm{~min}$ at $4{ }^{\circ} \mathrm{C}$, after which tubes were centrifuged $(30 \mathrm{~min}$, $3000 \mathrm{~g}$ ). Pellets were then stabilised by the addition of $50 \mu \mathrm{l}$ of $5 \%(\mathrm{w} / \mathrm{v})$ potato starch and tubes were recentrifuged (15 min, $3000 \mathrm{~g}$ ), drained and counted in a $\delta$-counter. A typical standard curve ranged from 0.08 to $40 \mathrm{pg} / 100 \mu \mathrm{l}\left(\mathrm{ED}_{50}=5 \cdot 4 \mathrm{pg} / 100 \mu \mathrm{l}\right)$ with the sensitivity of the assay being $0.8 \mathrm{pg} / \mathrm{ml}$. Samples were assayed in triplicate at multiple dilutions across two to three assays. The within-assay variation was $6.0 \%$, and the betweenassay variation was $23 \%$. The specificity of the primary antibody has been described by the manufacturer, which includes cross-reactivities of $2 \cdot 40,0.64$ and $<0.01 \%$ for estrone, estriol and testosterone respectively. The crossreactivity of the ICI 182780 antagonist in this assay was determined to be $0.004 \%$, which at the dosage of antagonist given to the animals would correspond in the RIA to an approximately 40-fold increase in the oestradiol levels actually found in serum. While this calculation does not take into account removal by metabolic clearance, the potential for interference by the ICI antagonist in the RIA was considered too great to assay samples directly from these groups without prior separation.

\section{Statistics}

Statistical analyses were performed using Sigmastat for Windows version 2.0 (Jandel Corporation, CA, USA) with an initial assessment of homogeneity of variance for all groups. Homogeneous groups were assessed using one-way ANOVA, followed by the Newman-Keuls posthoc multiple comparisons test, or in the case of unequal variance, Dunn's method. The data were expressed as means \pm S.E.M, with $n=4-7$ rats per group.

\section{Results}

\section{Testicular weight}

GnRH immunisation reduced testicular weights to $18 \%$ of control levels $(P<0 \cdot 001$, Table 1$)$. Testosterone administration increased testicular weights $(P<0 \cdot 001)$ compared with GnRH-immunised rats (to 35\% of control values). Testosterone in combination with ICI 182780 had no effect on testicular weight compared with testosterone alone-treated rats (Table 1).

\section{Hormone levels}

Following GnRH immunisation, serum testosterone levels were suppressed to $7 \%$ of control values (Table 1). Serum testosterone levels were increased $(P<0 \cdot 001) \sim 100$-fold and more than 500-fold above GnRH-immunised control levels following treatment with T24 cm Silastic implants and T25 mg ester injections respectively. Administration of ICI 182780 had no effect on serum testosterone levels in T24 cm-treated rats compared with $\mathrm{T} 24 \mathrm{~cm}$ alone, however co-administration of ICI 182780 with testosterone ester reduced serum testosterone levels by $\sim 30 \%$ $(P<0 \cdot 01)$.

Serum FSH levels were suppressed by GnRH immunisation $(P<0 \cdot 001)$ to near the detection limit of the assay (Table 1). Following testosterone treatment alone, 
Table 2 The number of pachytene spermatocyte, round and elongated spermatids (millions) per testis in normal adult rats that were GnRH immunised for 12 weeks and then given testosterone ( $24 \mathrm{~cm}$ Silastic implant or $25 \mathrm{mg} / \mathrm{kg}$ injectable ester, every third day) alone or in combination with $\mathrm{ICl} 182780$ (ER ant) for 10 days

\begin{tabular}{|c|c|c|c|}
\hline & $\begin{array}{l}\text { Pachytene } \\
\text { spermatocytes } \\
\left(\times 10^{6}\right)\end{array}$ & $\begin{array}{l}\text { Round } \\
\text { spermatids } \\
\left(\times 10^{6}\right)\end{array}$ & $\begin{array}{l}\text { Elongated } \\
\text { spermatids } \\
\left(\times 10^{6}\right)\end{array}$ \\
\hline \multicolumn{4}{|l|}{ Treatment } \\
\hline Control & $142 \cdot 9 \pm 9 \cdot 02^{\mathrm{a}}$ & $398 \cdot 2 \pm 17 \cdot 2^{a}$ & $390 \cdot 5 \pm 33 \cdot 4^{a}$ \\
\hline GnRH-immunized & $17 \cdot 0 \pm 1 \cdot 29^{b}$ & $5 \cdot 26 \pm 1 \cdot 27^{b}$ & $0.13 \pm 0.06^{b}$ \\
\hline$+\mathrm{T} 24 \mathrm{~cm}$ & $78 \cdot 6 \pm 8 \cdot 37^{c}$ & $34 \cdot 2 \pm 4 \cdot 29^{c}$ & $1.95 \pm 0.79^{b}$ \\
\hline$+\mathrm{T} 24 \mathrm{~cm}+\mathrm{ER}$ ant & $78 \cdot 9 \pm 6 \cdot 15^{c}$ & $27 \cdot 8 \pm 1 \cdot 81^{\mathrm{c}}$ & $0 \cdot 38 \pm 0 \cdot 16^{b}$ \\
\hline +T25 mg & $78 \cdot 7 \pm 2 \cdot 99^{c}$ & $33 \cdot 7 \pm 3 \cdot 04^{\mathrm{c}}$ & $3 \cdot 41 \pm 1 \cdot 85^{\mathrm{c}}$ \\
\hline$+\mathrm{T} 25 \mathrm{mg}+\mathrm{ER}$ ant & $84 \cdot 1 \pm 8 \cdot 72^{\mathrm{C}}$ & $39 \cdot 2 \pm 5 \cdot 06^{\mathrm{C}}$ & $2 \cdot 03 \pm 0 \cdot 50^{c}$ \\
\hline
\end{tabular}

FSH levels were partially or completely restored in $\mathrm{T} 24 \mathrm{~cm}$ - and testosterone ester-treated rats respectively (Table 1). This rise in serum FSH was completely (T24 cm) or partially (testosterone ester) prevented following administration of ICI 182780, therefore showing that ICI 182780 had a biological effect at the pituitary level.

Serum LH was suppressed by GnRH immunisation to undetectable levels and remained so despite all subsequent hormone treatments (Table 1).

Serum oestradiol levels remained unchanged following GnRH immunisation (Table 1). Administration of $24 \mathrm{~cm}$ of testosterone did not alter serum oestradiol levels, however administration of testosterone esters increased serum oestradiol levels $(P<0 \cdot 01) 2$-fold above control levels.

Testicular oestradiol levels were increased 3.5-fold $(P<0 \cdot 05)$ following GnRH immunisation compared with control (Table 1). Testicular oestradiol levels tended to be lower following testosterone treatment compared with GnRH-immunised controls, however there was a high within-group variation and no statistical differences were seen.

\section{Germ cell estimates}

Suppression phase In response to $\mathrm{GnRH}$ immunisation, all germ cell numbers were suppressed $(P<0 \cdot 001)$ (Fig. 1 and Table 2): type A/intermediate spermatogonia and type B spermatogonia/preleptotene spermatocytes were reduced to $56 \%$ of control. Leptotene/zygotene spermatocytes were reduced to $63 \%$ of control, while pachytene spermatocytes were suppressed to $12 \%$ of control values. Round spermatids were $1 \%$ of control values, with only a few step 8 round spermatids observed. Similarly, only a few elongating spermatids were present while no elongated spermatids were seen.

Restoration phase In response to testosterone treatment (either T24 cm or T25 mg), type A/intermediate spermato- gonial number remained unchanged compared with the GnRH-immunised group (Fig. 1). Co-administration of ICI 182780 with testosterone had no impact on type $\mathrm{A} /$ intermediate spermatogonial number. In contrast, T25 mg increased $(P<0.05)$ type B spermatogonial/ preleptotene spermatocyte number above that of GnRHimmunised rats to $\sim 84 \%$ of control values, whereas T24 cm did not (Fig. 1). Co-administration of ICI 182780 with testosterone (T24 cm or T25 mg ester) made no difference to type B spermatogonial/preleptotene spermatocyte number. Both doses of testosterone tended to increase leptotene/zygotene spermatocyte number above that of GnRH-immunised rats to $\sim 85 \%$ of control values, although this did not achieve significance (Fig. 1). Again, co-administration of ICI 182780 with testosterone did not alter the leptotene/zygotene spermatocyte number (Fig. 1).

In response to both doses of testosterone treatment, the pachytene spermatocyte number was increased $(P<0 \cdot 001)$ to a similar extent to $55 \%$ of control values (Table 2$)$. The inhibition of oestrogen action did not affect this increase. Both doses of testosterone also increased round spermatid number $(P<0 \cdot 001)$ to $8 \%$ of control values, with coadministration of ICI 182780 again having no significant effect. Elongated spermatid number increased in response to T25 mg $(P<0 \cdot 01)$ but not following T24 cm treatment. Later spermatids (steps 15 to 19) were almost never seen. ICI 182780 treatment did not significantly affect elongated spermatid number.

\section{Discussion}

In this study we sought to establish whether the restoration of spermatogenesis by exogenous testosterone was influenced by its metabolite, oestrogen. The ER antagonist (ICI 182780) was administered, at a dose known to impair oestrogen action in the male reproductive tract (Oliveira et al. 2001, 2002, Cho et al. 2003), during high-dose 

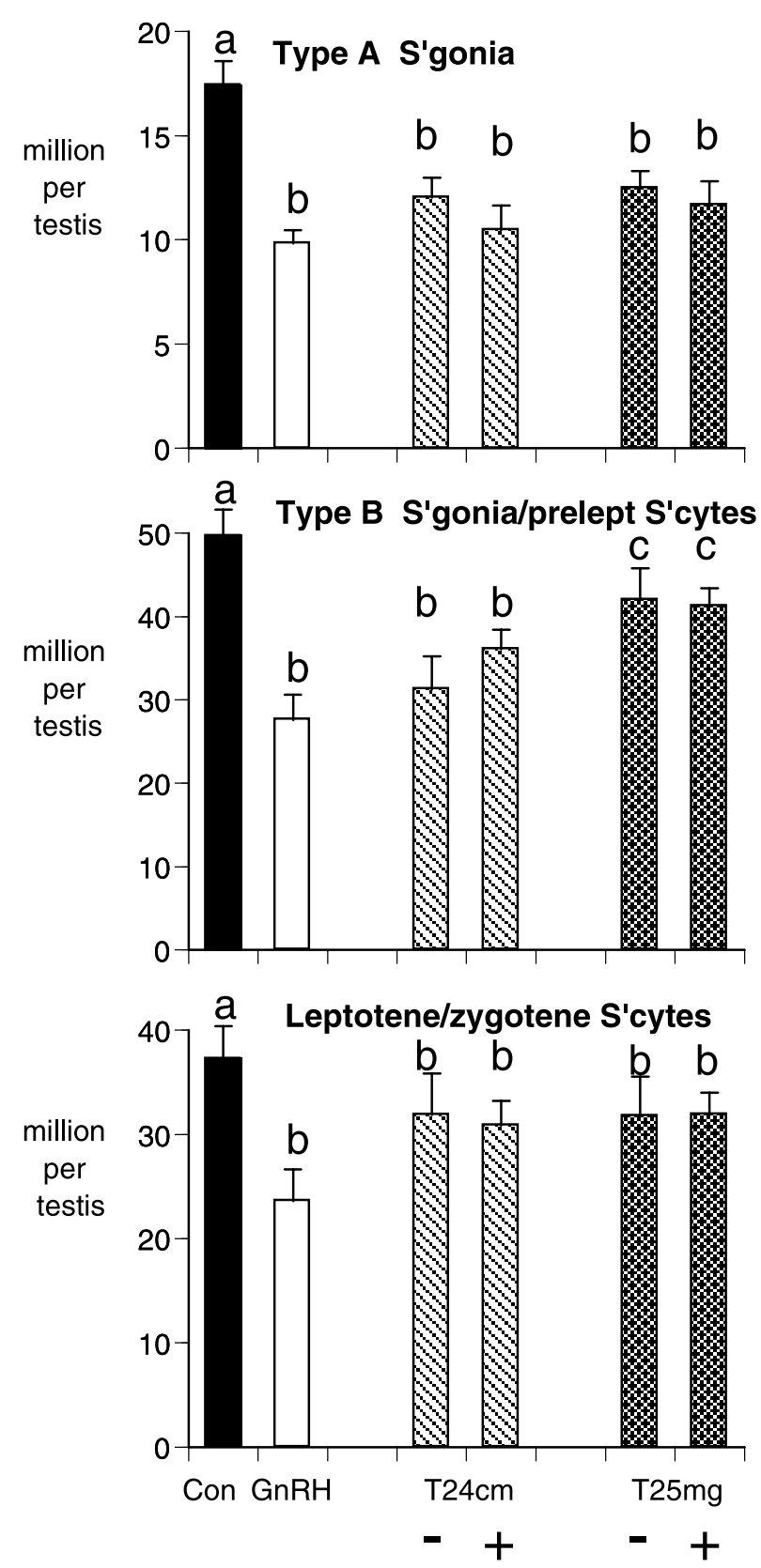

Figure 1 The number of type $\mathrm{A} /$ intermediate spermatogonia, type B spermatogonia/preleptotene spermatocytes and leptotene/zygotene spermatocytes (millions) per testis in normal adult rats that were $\mathrm{GnRH}$ - immunised for 12 weeks and then given testosterone $(24 \mathrm{~cm}$ Silastic implant or $25 \mathrm{mg} / \mathrm{kg}$ injectable ester, every third day) alone or in combination with an oestrogen receptor antagonist (ICl 182780) for 10 days. Data are means \pm S.E.M., $n=6-8$ rats per group. Letters denotes significant differences between groups at or less than $P<0.05$ (see text for specifics). - , absence of ER antagonist; +, presence of ER antagonist. testosterone treatment of GnRH-immunised rats. Two effects were observed. First, the inhibition of spermatogonial number induced by supra-physiological levels of testosterone in $\mathrm{GnRH}$-immunised rats was not affected by administration of the ER antagonist ICI 182780. Secondly, the supportive effect of testosterone on pachytene spermatocytes was not altered by the blockade of oestrogen action. It is concluded that the inhibition of ER action does not provide a micro environment conducive to restoration of type A spermatogonial numbers over the 10-day time frame of the study, nor does oestrogen action contribute to testosterone-induced stimulation of postmeiotic germ cells.

To antagonise local oestrogen action in the testis, this study employed a similar dose ( $\mathrm{g} / \mathrm{kg}$ body weight) of ICI 182780 to that reported elsewhere in rats to cause significant changes to both testis weight and dilation of seminiferous tubules after 52 days of treatment, and severe atrophy by day 150 (Oliveira et al. 2001). These testicular effects were probably a result of an accumulation of fluid following inhibition of reabsorption in the efferent ductules (Oliveira et al. 2001), similar to the phenotype seen in the ER $\alpha$-deficient mouse (Eddy et al. 1996). In a follow-up study these authors confirmed that changes in the efferent ductules preceded those in the testes indicating that the testicular effects of ICI 182780-treated rats were secondary to the epididymal effects (Oliveira et al. 2002). These data confirm that the antagonist doses used in our study would be expected to substantially impair ER-mediated effects, consistent with the observation of a suppression of serum FSH in this study.

\section{Germ cell regulation}

The GnRH-immunised rat model displays wellcharacterised reductions in all germ cell types (McLachlan et al. 1995, Meachem et al. 1998) but especially developmental arrest in mid-spermiogenesis (McLachlan et al. 1994a). Administration of testosterone (doses of 6 and $24 \mathrm{~cm}$ Silastic implants) to GnRH-immunised rats promptly restores serum FSH by a $\mathrm{GnRH}$-independent mechanism and hence this model is one of acute testosterone and FSH restoration (McLachlan et al. 1994a, Meachem et al. 1998). However, for reasons that are unclear, this increase in serum FSH has not always been reported by others in testosterone-treated GnRHimmunised rats (Awoniyi et al. 1989).

In regard to the hormonal regulation of spermatogonial number, in the GnRH-immunised rat model FSH is required for their restoration (McLachlan et al. 1995, Meachem et al. 1998) with low testosterone $(6 \mathrm{~cm})$ being ineffective in restoring spermatogonial number in the absence of FSH (Meachem et al. 1998). High-dose serum testosterone (5-fold normal as induced by $\mathrm{T} 24 \mathrm{~cm}$ (Meachem et al. 1998)), independent of FSH action, fails to increase spermatogonial number above that of the 
GnRH-immunised rat (Ebling et al. 2000). High-dose testicular testosterone (4-fold normal) observed after irradiation in rats has been found elsewhere to inhibit spermatogonial differentiation, and lowering these levels, even transiently, was sufficient to enhance the recovery of spermatogonia (Ogawa et al. 1999). Therefore it was postulated that metabolism of testosterone to oestrogen by aromatisation may impair spermatogonial development (Meistrich \& Kangasniemi 1997). This explanation seems plausible considering that ER $\beta$ has been immunolocalised to rat Sertoli cells and spermatogonia (Saunders et al. 1998). However, our data demonstrate that treatment of rats with ICI 182780 did not ameliorate the proposed inhibitory effects of high levels of testosterone on spermatogonial numbers, suggesting that it is not oestrogenic in nature. Alternative mechanisms for the inhibitory effects of high-dose testosterone on spermatogonial number could include: (i) that testosterone itself acts in this fashion in these specialised settings; (ii) that testosterone treatment results in the production of an additional product arising from elsewhere (e.g. in the liver); or (iii) another metabolite of testosterone, such as its 5-alpha-reduced product DHT, may be involved, noting that the administration of testosterone to GnRH-immunised rats elevated testicular DHT levels (Pratis et al. 2003).

Evidence supporting an oestrogenic effect(s) on spermatogonial development is lacking. Consistent with this, spermatogonial numbers are normal in mice lacking a functional aromatase gene (Robertson et al. 1999) suggesting that oestrogen plays no role in this model. Transplantation of ER $\alpha$-deficient germ cells into wild-type testes resulted in qualitatively normal spermatogenesis (Mahato et al. 2000). However, an ER $\beta$-directed mechanism is plausible given that ER $\beta$ receptors are present on spermatogonia (Saunders et al. 1998), but no similar transplantation experiment has been reported with ER $\beta$-deficient germ cells.

Our data show that testosterone supports type B spermatogonial and primary spermatocyte development and that this effect is independent of oestrogen action as it was unaffected by ICI 182780 treatment. Furthermore, the action of testosterone presumably involves enhanced cell survival or mitosis of type B spermatogonia rather than increased precursor cell entry since type A spermatogonial number was unaffected. Other reports suggest that testosterone supports type B spermatogonial and primary spermatocyte number independent of type A spermatogonia (Meachem et al. 1997, El Shennawy et al. 1998, Franca et al. 1998, Russell et al. 1998) and that testosterone exerts its effects by preventing their degeneration (El Shennawy et al. 1998, Russell et al. 1998).

Exogenous testosterone support for meiosis and early spermiogenesis has been widely reported in rats (Muffly et al. 1993, 1994, McLachlan et al. 1994b, O’Donnell et al. 1996a, Saito et al. 2000) and genetically modified mice models (Chang et al. 2004, De Gendt et al. 2004,
Spaliviero et al. 2004). Oestrogen receptor inhibition in this study had no effect on the restoration of spermatocyte and spermatid number by testosterone. This is consistent with other studies (Chen et al. 1994, Singh et al. 1995) suggesting that aromatisation is not required to support spermatogenesis; however it has been shown elsewhere that early spermiogenesis is sensitive to oestrogen action (Robertson et al. 1999). Although testicular testosterone was not measured in the current study due to the limited amount of available tissue, our previous reports have consistently shown that $\mathrm{T} 24 \mathrm{~cm}$ treatment of GnRHimmunised rats elevates total testicular testosterone levels to $\sim 10 \%$ of control levels (Meachem et al. 1998, Pratis et al. 2003), compared with $3 \%$ in the GnRH-immunised control. Using the same rat model, others have demonstrated an elevation in interstitial fluid testosterone to $\sim 20 \%$ of control following T24 cm treatment (Awoniyi et al. 1989, 1992), with this variation most likely to be due to the different assay systems and tissues measured. While the effect of T25 mg esters on testicular testosterone has not previously been determined in this model, it is considered that this treatment would elevate testosterone to $\sim 20 \%$ of control levels; this assumption is based on data where the same treatment was administered to rats selectively withdrawn of testicular testosterone by lowdose testosterone and oestrogen implants, where testicular testosterone also falls to 3\% of control (Meachem et al. 1997). Numerous studies (Boccabella 1963, Cunningham \& Huckins 1979, Marshall et al. 1984) have reported that spermatogenesis can be maintained with $10-20 \%$ of normal testicular testosterone.

This study also highlights that germ cell types have differing dependencies for testosterone. Support of type B spermatogonia (El Shennawy et al. 1998, Meachem et al. 1998), spermatocytes (McLachlan et al. 1994b, Meachem et al. 1997, 1998) and spermatid maturation (McLachlan et al. 1994b, Meachem et al. 1997, 1998, O’Donnell et al. $1996 a, b, 1999)$ requires testicular testosterone, albeit at much lower levels ( 10-20\% of control) than the normal setting produces (Boccabella 1963, Cunningham \& Huckins 1979, Marshall et al. 1984). In contrast, testosterone provides no support for the restoration of type A spermatogonial number (Meachem et al. 1997, 1998), while supraphysiological levels of serum (Meachem et al. 1997, 1998) and testicular testosterone (Meistrich \& Kangasniemi 1997, Matsumiya et al. 1999, Meistrich et al. 1999, Shuttlesworth et al. 2000, Shetty \& Weng 2004) have a detrimental effect on type A spermatogonial development. The mechanism(s) behind this differential response is not known.

\section{Hypothalamo-pituitary-testicular axis regulation}

Serum FSH levels were significantly reduced by concomitant ICI 182780 administration providing support for the notion that oestrogen acts in a positive manner on the 
male pituitary. Others have noted a stimulatory effect of low-dose oestrogen on FSH in neonatal (Tena-Sempere et al. 2000) and $h p g$ mice (Ebling et al. 2000). In the setting where the hypothalamic-pituitary axis is intact, it is clear that oestrogen exerts an inhibitory effect on gonadotrophin secretion (de Jong et al. 1975, reviewed in O'Donnell et al. 2001). GnRH facilitates FSH secretion directly from the pituitary by augmenting the $\mathrm{GnRH}$ receptor signal transduction pathway, with oestrogen also being able to facilitate this pathway and stimulate FSH secretion (reviewed in Shupnik 1996). Presumably in our study, in the absence of effective GnRH action on the gonadotrophs, oestrogen (via metabolism from exogenous testosterone) promotes the release of FSH and the ER antagonist inhibits this effect. Taken together these data indicate that oestrogen can participate in both negative and positive effects on the pituitary in the male.

\section{Oestradiol concentrations}

Studies describing oestrogen concentrations in the male reproductive tract are reviewed elsewhere (Hess 2000). Rat serum oestradiol concentrations in this study are similar to those reported by de Jong and colleagues (de Jong et al. 1973). While rat whole testicular oestradiol concentrations have not previously been described, oestradiol concentrations in the testicular vein (de Jong et al. 1973), seminiferous tubules (de Jong et al. 1974) and rete testis (Free \& Jaffe 1979) have been reported. Our testicular oestradiol data are in agreement with levels reported in dissected seminiferous tubules (de Jong et al. 1974), with concentrations within the seminiferous epithelium being nine times higher than in serum (de Jong et al. 1974). In this study testicular oestradiol levels, regardless of hormonal manipulation, were $\sim 10$-fold higher than circulating levels, consistent with de Jong and colleagues (de Jong et al. 1973) and data from a variety of species (reviewed in de Jong et al. 1973).

Unexpectedly, serum concentrations of oestradiol in GnRH-immunised rats remained at control levels, while oestradiol concentrations in the testis were elevated 3-fold above control values, even in the presence of very low levels of testicular testosterone (3\% of control, (Meachem et al. 1998, McLachlan et al. 1994a)). Testicular oestradiol concentrations may be elevated in this gonadotrophindepleted model for one of several reasons. (1) Oestrogen production in the rat may be, at least in part, GnRH independent. Other tissues such as adipose tissue (preadipocytes and stromal mesenchymal cells) and bone (osteoblasts) produce oestrogen and are not under $\mathrm{GnRH}$ control (reviewed in Simpson et al. 2002). Cytokines, such as tumour necrosis factor (TNF)- $\alpha$ and interleukin (IL)-11, regulate oestrogen production in these tissues (reviewed in Simpson et al. 2002). As TNF- $\alpha$ and IL have been described in the testis, these cytokines may play a local role (reviewed in Gnessi et al. 1997). It has been shown that low levels of testicular testosterone are constitutively present in gonadotrophin-depleted mice suggesting a GnRH-independent mode of testosterone production (Zhang et al. 2003), which may also be true for oestrogen. (2) Testosterone may negatively regulate aromatase activity, thus aromatase activity may be upregulated in the GnRH-immunised model resulting in an increase in oestrogen levels. Presumably only Leydig and/or Sertoli cell aromatase activity would contribute to this effect, since germ cell loss is extensive in GnRHimmunised animals. (3) It may be possible that oestrogen metabolism was altered in the GnRH-immunised rat and as a consequence oestradiol accumulated. Serum and testicular oestradiol concentrations were not determined in the ICI 182780 antagonist-treated rats in this study because the antagonist cross-reacted in the oestradiol RIA.

It is concluded that oestrogen action plays no role in the short-term restoration of spermatogenesis by testosterone in the GnRH-immunised rat. More particularly, the failure of high-dose testosterone to fully restore type A spermatogonia is not ameliorated by inhibition of ER action, and no evidence was found for the modulation of later germ cell progression by oestrogen. This study also provides new data regarding oestradiol concentrations in gonadotrophin-depleted rats, with an unexplained increase in testicular oestradiol concentrations in this model. In addition, this study provides further evidence that oestrogen can participate in the positive regulation of pituitary $\mathrm{FSH}$ in the rat in the absence of $\mathrm{GnRH}$ bioactivity.

\section{Acknowledgements}

The authors would like to thank Fiona McLean for her excellent technical assistance in this study. RIA reagents for the rat FSH assay were provided by NIDDK.

\section{Funding}

This study was supported by the Lalor Foundation, USA, Wellcome Trust Fellow Scheme, UK (grant 058479 to S M) and the National Health and Medical Research Council of Australia (grant 241000 to S M, D M R, R M , $\mathrm{PS}$ ). The authors declare that there is no conflict of interest that would prejudice the impartiality of this scientific work.

\section{References}

Awoniyi CA, Santulli R, Chandrashekar V, Schanbacher, BD \& Zirkin BR 1989 Quantitative restoration of advanced spermatogenic cells in adult male rats made azoospermic by active immunization against luteinizing hormone or gonadotrophin-releasing hormone. Endocrinology 125 1303-1309.

Awoniyi CA, Zirkin BR, Chandrashekar V \& Schlaff WD 1992 Exogenously administered testosterone maintains spermatogenesis 
quantitatively in adult rats actively immunized against gonadotropin-releasing hormone. Endocrinology 130 3283-3288.

Boccabella AV 1963 Reinitiation and restoration of spermatogenesis with testosterone propionate and other hormones after long-term post-hypophysectomy regression period. Endocrinology 72 787-798.

Chang C, Chen YT, Yeh SD, Xu Q, Wang RS, Guillou F, Lardy H \& Yeh S 2004 Infertility with defective spermatogenesis and hypotestosteronemia in male mice lacking the androgen receptor in Sertoli cells. PNAS 101 6876-6881.

Chen H, Chandrashekar V \& Zirkin BR 1994 Can spermatogenesis be maintained quantitatively in intact adult rats with exogenously administered dihydrotestosterone? Journal of Andrology 15 132-138.

Cho HW, Nie R, Carnes K, Zhou Q, Sharief NA \& Hess RA 2003 The antiestrogen ICI 182,780 induces early effects on the adult male mouse reproductive tract and long-term decreased fertility without testicular atrophy. Reproductive Biology and Endocrinology 18 57.

Couse JF, Hewitt SC, Bunch DO, Sar M, Walker VR, Davis BJ \& Korach KS 1999 Postnatal sex reversal of the ovaries in mice lacking estrogen receptors alpha and beta. Science 286 2328-2331.

Cunningham GR \& Huckins C 1979 Persistence of complete spermatogenesis in the presence of low intratesticular concentrations of testosterone. Endocrinology 105 177-186.

Dao B, Vanage A, Marshall C, Bardin W \& Koide SS 1996 Anti-implantation activity of antiestrogens and mifespristone. Contraception 253-258.

De Gendt K, Swinnen JV, Saunders PT, Schoonjans L, Dewerchin M, Devos A, Tan K, Atanassova N, Claessens F, Lecureuil C, Heyns W, Carmeliet P, Guillou F, Sharpe RM \& Verhoeven G 2004 A Sertoli cell-selective knockout of the androgen receptor causes spermatogenic arrest in meiosis. PNAS 101 1327-1332.

Dupont S, Krust A, Gansmuller A, Dierich A, Chambon P \& Mark M 2000 Effect of single and compound knockouts of estrogen receptors alpha (ERalpha) and beta (ERbeta) on mouse reproductive phenotypes. Development 127 4277-4291.

Ebling FJ, Brooks AN, Cronin AS, Ford H \& Kerr JB 2000 Estrogenic induction of spermatogenesis in the hypogonadal mouse. Endocrinology 141 2861-2869.

Eddy EM, Washburn TF, Bunch DO, Goulding EH, Gladen BC, Lubahn DB \& Korach KS 1996 Targeted disruption of the estrogen receptor gene in male mice causes alteration of spermatogenesis and infertility. Endocrinology 137 4796-4805.

El Shennawy A, Gates RJ \& Russell LD 1998. Hormonal regulation of spermatogenesis in the hypophysectomized rat: cell viability after hormonal replacement in adults after intermediate periods of hypophysectomy. Joural of Andrology 19 320-334.

Franca LR, Parreira GG, Gates RJ \& Russell LD 1998 Hormonal regulation of spermatogenesis in the hypophysectomized rat: quantitation of germ-cell population and effect of elimination of residual testosterone after long-term hypophysectomy. Journal of Andrology 19 335-340; discussion 341-342.

Free MJ \& Jaffe RA 1979 Collection of rete testis fluid from rats without previous efferent duct ligation. Biology of Reproduction 20 269-278.

Gnessi L, Fabbri A \& Spera G 1997 Gonadal peptides as mediators of development and functional control of the testis: an integrated system with hormones and local environment. Endocrine Reviews $\mathbf{1 8}$ 541-609.

Haavisto AM, Pettersson K, Bergendahl M, Perheentupa A, Roser JF \& Huhtaniemi I 1993 A supersensitive immunofluorometric assay for rat luteinizing hormone. Endocrinology 132 1687-1691.

Hess R 2000 Oestrogen in fluid transport in efferent ducts of the male reproductive tract. Reviews of Reproduction 5 84-92.

Hess RA, Bunick D, Lee KH, Bahr J, Taylor JA, Korach KS \& Lubahn DB 1997 A role for oestrogens in the male reproductive system. Nature 390 509-512.

Howell A, Robertson JF, Quaresma Albano J, Aschermannova A, Mauriac L, Kleeberg UR, Vergote I, Erikstein B, Webster A \&
Morris C 2002 Fulvestrant, formerly ICI 182,780, is as effective as anastrozole in postmenopausal women with advanced breast cancer progressing after prior endocrine treatment. Journal of Clinical Oncology 20 3396-3403.

Huang HF, Marshall GR, Rosenberg R \& Nieschlag E 1987 Restoration of spermatogenesis by high levels of testosterone in hypophysectomized rats after long-term regression. Acta Endocrinologica 116 433-444.

de Jong F, Hey A \& van der Molen H 1973 Effects of gonadotrophins on the secretion of oestradiol- $17 \beta$ and testosterone by the rat testis. Journal of Endocrinology 57 277-284.

de Jong FH, Hey AH \& van der Molen HJ 1974 Oestradiol-17 $\beta$ and testosterone in rat tissue: effect of gonadotrophins, localization and production in vitro. Journal of Endocrinology 60 409-419.

de Jong FH, Uilenbroek TJ \& van der Molen HJ 1975 Oestradiol$17 \beta$, testosterone and gonadotrophins in oestradiol-17 $\beta$-treated intact adult male rats. Journal of Endocrinology 65 281-282.

Krege JH, Hodgin JB, Couse JF, Enmark E, Warner M, Mahler JF, Sar M, Korach KS, Gustafsson JA \& Smithies O 1998 Generation and reproductive phenotypes of mice lacking estrogen receptor beta. PNAS 95 15677-15682.

Kuiper GGJM, Carlsson B, Grandien K, Enmark E, Haggblad J, Nilsson S \& Gustafsson J-A 1997 Comparison of the ligand binding specificity and transcript tissue distribution of oestrogen receptors alpha and beta. Endocrinology 138 863-870.

McLachlan RI, Wreford NG, Tsonis C, de Kretser DM \& Robertson DM 1994a Testosterone effects on spermatogenesis in the gonadotrophin-releasing hormone-immunized rat. Biology of Reproduction 50 271-280.

McLachlan RI, Wreford NG, Meachem SJ, de Kretser DM \& Robertson DM $1994 b$ Effects of testosterone on spermatogenic cell populations in the adult rat. Biology of Reproduction 51 945-955.

McLachlan RI, Wreford NG, de Kretser DM \& Robertson DM 1995 The effects of recombinant follicle-stimulating hormone on the restoration of spermatogenesis in the gonadotropin-releasing hormone-immunized adult rat. Endocrinology 136 4035-4043.

McLachlan RI, O’Donnell L, Meachem SJ, Stanton PG, de Kretser DM, Pratis K \& Robertson DM 2002 Identification of specific sites of hormonal regulation in spermatogenesis in rats, monkeys and man. Recent Progress in Hormone Research 57 149-179.

Mahato D, Goulding EH, Korach KS \& Eddy EM 2000 Spermatogenic cells do not require estrogen receptor-alpha development or function. Endocrinology 141 1273-1276.

Marshall GR, Wickings, EJ \& Nieschlag E 1984 Testosterone can initiate spermatogenesis in the immature nonhuman primate, Macaca fascicularis. Endocrinology 114 2228-2233.

Matsumiya K, Meistrich ML, Shetty G, Dohmae K, Tohda A, Okuyama A \& Nishimune Y 1999 Stimulation of spermatogonial differentiation in juvenile spermatogonial depletion (jsd) mutant mice by gonadotropin-releasing hormone antagonist treatment. Endocrinology 140 4912-4915.

Meachem SJ, McLachlan RI, de Kretser DM, Roberston DM \& Wreford NG 1996 Neonatal exposure of rats to recombinant follicle stimulating hormone increases adult Sertoli and spermatogenic cell numbers. Biology of Reproduction 54 36-44.

Meachem SJ, Wreford NG, Robertson DM \& McLachlan RI 1997 Androgen action on the restoration of spermatogenesis in adult rats: effects of human chorionic gonadotrophin, testosterone and flutamide administration on germ cell number. International Journal of Andrology 20 70-79.

Meachem SJ, Wreford NG, Stanton PG, Robertson DM \& McLachlan RI 1998 Follicle-stimulating hormone is required for the initial phase of spermatogenic restoration in adult rats following gonadotrophin suppression. Journal of Andrology 19 725-735.

Meachem SJ, McLachlan RI, Stanton PG, Robertson DM \& Wreford NG 1999 FSH immunoneutralization acutely impairs spermatogonial development in normal adult rats. Journal of Andrology 20 756-762. 
Meistrich ML \& Kangasniemi M 1997 Hormone treatment after irradiation stimulates recovery of rat spermatogenesis from surviving spermatogonia. Journal of Andrology 18 80-87.

Meistrich ML, Wilson G \& Huhtaniemi I 1999 Hormonal treatment after cytotoxic therapy stimulates recovery of spermatogenesis. Cancer Research 59 3557-3560.

Muffly KE, Nazian SJ \& Cameron DF 1993 Junction-related Sertoli cell cytoskeleton in testosterone-treated hypophysectomised rats. Biology of Reproduction 49 1122-1132.

Muffly KE, Nazian SJ \& Cameron DF 1994 Effects of folliclestimulating hormone on the junction-related Sertoli cell cytoskeleton and daily sperm production in testosterone-treated hypophysectomised rats. Biology of Reproduction 51 158-166.

O'Donnell L, McLachlan RI, Wreford NG, de Kretser DM \& Robertson, DM 1996a Testosterone withdrawal promotes stage-specific detachment of round spermatids from the rat seminiferous epithelium. Biology of Reproduction 55 895-901.

O'Donnell L, Stanton PG, Wreford NG, Robertson DM \& McLachlan RI $1996 b$ Inhibition of $5 \alpha$-reductase activity impairs the testosterone-dependent restoration of spermiogenesis in adult rats. Endocrinology 137 2703-2710.

O’Donnell L, Pratis K, Stanton PG, Robertson DM \& McLachlan RI 1999 Testosterone-dependent restoration of spermatogenesis in adult rats is impaired by a 5 alpha-reductase inhibitor. Journal of Andrology 20 109-117.

O'Donnell L, Robertson KM, Jones ME \& Simpson ER 2001 Estrogen and spermatogenesis. Endocrine Reviews 22 289-318.

Ogawa T, Dobrinski I \& Brinster RL 1999 Recipient preparation is critical for spermatogonial transplantation in the rat. Tissue Cell $\mathbf{3 1}$ 461-472.

Oliveira CA, Carnes K, Franca LR \& Hess RA 2001 Infertility and testicular atrophy in the antiestrogen-treated adult male rat. Biology of Reproduction 65 913-920.

Oliveira CA, Zhou Q, Carnes K, Nie R, Kuehl DE, Jackson GL, Franca LR, Nakai M \& Hess RA 2002 ER function in the adult male rat: short- and long-term effects of the antiestrogen ICI 182,780 on the testis and efferent ductules, without changes in testosterone. Endocrinology 143 2399-2409.

Pratis K, O'Donnell L, Ooi GT, Stanton PG, McLachlan RI \& Robertson DMJ 2003 Differential regulation of rat testicular 5 alpha-reductase type 1 and 2 isoforms by testosterone and FSH. Endocrinology 176 393-403.

Robaire B, Ewing LL, Irby DC \& Desjardings C 1979 Interactions of testosterone and oestradiol- $17 \beta$ on the reproductive tract of the male rat. Biology of Reproduction 21 455-463.

Robertson KM, O'Donnell L, Jones ME, Meachem SJ, Boon WC, Fisher CR, Graves KH, McLachlan RI \& Simpson ER 1999 Impairment of spermatogenesis in mice lacking a functional aromatase (cyp 19) gene. PNAS 96 7986-7991.

Russell LD, Ettlin RA, Sinha Hikim AP \& Clegg ED 1990 Histological and Histopathological Evaluation of the Testis. FL, USA: Cache River Press.

Russell LD, Kershaw M, Borg KE, El Shennawy A, Rulli SS, Gates RJ \& Calandra RS 1998 Hormonal regulation of spermatogenesis in the hypophysectomized rat: FSH maintenance of cellular viability during pubertal spermatogenesis. Journal of Andrology 19 308-319; discussion 341-342.

Saito K, O’Donnell L, McLachlan RI \& Robertson DM 2000 Spermiation failure is a major contributor to early spermatogenic suppression caused by hormone withdrawal in adult rats. Endocrinology 141 2779-2785.
Saunders PTK, Maguire SM, Gaughan J \& Millar MR 1998 Expression of oestrogen receptor beta $(\mathrm{ER} \beta)$ in multiple rat tissues visualised by immunohistochemistry. Journal of Endocrinology 154 R13-R16.

Shetty G \& Weng CC 2004 Cryptorchidism rescues spermatogonial differentiation in juvenile spermatogonial depletion (jsd) mice. Endocrinology 145 126-133.

Shupnik MA 1996 Gonadotropin gene modulation by steroids and gonadotropin-releasing hormone. Biology of Reproduction 54 279-286.

Shuttlesworth GA, de Rooij DG, Huhtaniemi I, Reissmann T, Russell LD, Shetty G, Wilson G \& Meistrich ML 2000 Enhancement of A spermatogonial proliferation and differentiation in irradiated rats by gonadotropin-releasing hormone antagonist administration. Endocrinology 141 37-49.

Simpson ER, Clyne C, Rubin G, Boon WC, Robertson K, Britt K, Speed C \& Jones M 2002 Aromatase-a brief overview. Annual Review of Physiology 64 93-127.

Singh J, O'Neill C \& Handelsman DJ 1995 Induction of spermatogenesis by androgens in gonadotropin-deficient $(\mathrm{hpg})$ mice. Endocrinology 136 5311-5321.

Spaliviero JA, Jimenez M, Allan CM \& Handelsman DJ 2004 Luteinizing hormone receptor-mediated effects on initiation of spermatogenesis in gonadotropin-deficient (hpg) mice are replicated by testosterone. Biology of Reproduction 70 32-38.

Stewart A, Valentine J, Tsonis C, Borchers C, Russell-Jone G, Headon D, Worral M, Clifton G, McInerney B \& Forage R 1992 Immunisation using recombinant TraT-LHRH fusion proteins. In Vaccines, pp 51-55. Eds F Brown, RM Chaneck, H Ginsberg \& RE Lerner. Cold Spring Harbor: Cold Spring Harbor Laboratory.

Sun YT, Irby DC, Robertson DM \& de Kretser D 1989 The effects of exogenously administered testosterone on spermatogenesis in intact and hypophysectomized rats. Endocrinology 125 1000-1010.

Tena-Sempere M, Navarro J, Pinilla L, Gonzalez LC, Huhtaniemi I \& Aguilar E 2000 Neonatal exposure to estrogen differentially alters estrogen receptor alpha and beta mRNA expression in rat testis during postnatal development. Journal of Endocrinology 165 345-357.

Tremblay GB, Tremblay A, Labrie F \& Giguere V 1998 Ligand-independent activation of the estrogen receptors alpha and beta by mutations of a conserved tyrosine can be abolished by antiestrogens. Cancer Research 58 877-881.

Wakeling AE 2000 Similarities and distinctions in the mode of action of different classes of antioestrogens. Endocrine Related Cancer 7 $17-28$.

Wreford NG 1995 Theory and practice of stereological techniques applied to the estimation of cell number and nuclear volume in the testis. Microscopy Research and Technique 32 423-436.

Zhang FP, Pakarainen T, Poutanen M, Toppari J \& Huhtaniemi I 2003 The low gonadotropin-independent constitutive production of testicular testosterone is sufficient to maintain spermatogenesis. PNAS 100 13692-13697.

Zhou Q, Clarke L, Nie R, Carnes K, Lai LW, Lien YH, Verkman A, Lubahn D, Fisher JS, Katzenellenbogen BS \& Hess RA 2001 Estrogen action and male fertility: roles of the sodium/hydrogen exchanger- 3 and fluid reabsorption in reproductive tract function. PNAS 8 14132-14137.

Received 4 March 2005

Accepted 9 March 2005 